\title{
Biological and social aspects of Coronavirus Disease 2019 (COVID-19) related to oral health
}

\author{
Luciano José PEREIRA ${ }^{(a)}$ \\ Cassio Vicente PEREIRA ${ }^{(b)}$ (iD \\ Ramiro Mendonça MURATA(c) \\ Vanessa PARDI(c) \\ Stela Márcia PEREIRA-DOURADO(a) \\ (a) Universidade Federal de Lavras - UFLA, \\ Departamento de Ciências da Saúde, \\ Lavras, MG, Brazil. \\ (b) Centro Universitário de Lavras - Unilavras, \\ Faculdade de Odontologia, Lavras, \\ MG, Brazil. \\ (c) East Carolina University - ECU, School of \\ Dental Medicine, Greenville, SC, USA.
}

Declaration of Interests: The authors certify that they have no commercial or associative interest that represents a conflict of interest in connection with the manuscript.

\section{Corresponding Author:}

Luciano José Pereira

E-mail: lucianopereiraufla@gmail.com

https://doi.org/10.1590/1807-3107bor-2020.vol34.0041

Submitted: April 7, 2020

Accepted for publication: April 13, 2020

Last revision: April 14, 2020
Abstract: The expansion of coronavirus disease 2019 (COVID-19) throughout the world has alarmed all health professionals. Especially in dentistry, there is a growing concern due to it's high virulence and routes of transmission through saliva aerosols. The virus keeps viable on air for at least 3 hours and on plastic and stainless-steel surfaces up to 72 hours. In this sense, dental offices, both in the public and private sectors, are high-risk settings of cross infection among patients, dentists and health professionals in the clinical environment (including hospital's intensive dental care facilities). This manuscript aims to compile current available evidence on prevention strategies for dental professionals. Besides, we briefly describe promising treatment strategies recognized until this moment. The purpose is to clarify dental practitioners about the virus history and microbiology, besides guiding on how to proceed during emergency consultations based on international documents. Dentists should consider that a substantial number of individuals (including children) who do not show any signs and symptoms of COVID-19 may be infected and can disseminate the virus. Currently, there is no effective treatment and fast diagnosis is still a challenge. All elective dental treatments and non-essential procedures should be postponed, keeping only urgent and emergency visits to the dental office. The use of teledentistry (phone calls, text messages) is a very promising tool to keep contact with the patient without being at risk of infection.

Keywords: Coronavirus; Public Health; Practice Management, Dental; Infections; Dentistry.

\section{Introduction}

Coronavirus is a family of viruses that causes respiratory infections including the new coronavirus (SARS-CoV-2) discovered in December 2019 in China. Coronaviruses represent enveloped, positive stranded RNA virus that contains four genera: Alpha-, Beta-, Gamma-, and Deltacoronavirus. ${ }^{1}$ Six different coronavirus have been identified in humans: HCoV-OC43,-229E, HCoV-NL63, HKU1, the Middle East respiratory syndrome (MERS)-CoV and (SARS)-CoV. ${ }^{2}$ Although the latter virus became widely discussed recently, the first human coronaviruses were isolated for the first time in 1937. ${ }^{3}$ The denomination coronavirus was due to its microscopic aspect 
resembling crown-like spikes on its surface and the main host receptor for humans seems to be the angiotensin-converting enzyme 2 (ACE2). ${ }^{4}$

This recent COVID-19 turned into a global public health outbreak. ${ }^{5,6}$ It is transmitted after contact with infected surfaces and with infected patient's fluids, including saliva and aerosol. ${ }^{6,7}$ These characteristics place the dental offices as main risk settings of cross infection among patients, dentists and health professionals in the clinical environment, including hospital's dental intensive care facilities. ${ }^{8}$ Dental practitioners are exposed to close contact to patients, to saliva aerosol, blood and handle sharp contaminated instruments. ${ }^{9}$

After the World Health Organization (WHO) pandemic declaration, institutions like the General Coordination of Oral Health from the Brazilian Health Ministry published a Technical Note with the main clarifications regarding dental practice considering the Coronavirus pandemic. ${ }^{10}$ Centers for Disease Control and Prevention (CDC) and American Dental Association (ADA) are recommending dentists to postpone elective procedures and concentrating on emergency or urgent dental care in order to reduce COVID-19 infection, ${ }^{11,12}$ similar to what several cities in China have done. ${ }^{13}$

As health professionals, it is extremely relevant that dentists be aware of the biological and social characteristics involved in COVID-19 pandemic, contributing to the clarification of the population and adopting finest clinical measures to avoid unnecessary risks to contain the perioperative transmission. ${ }^{8}$ Based on the current available evidence related to oral health care, the aim of the present critical appraisal is to compile prevention strategies for dental professionals and clarify dental practitioners about the virus history, pathogenesis, current pharmacological clinical trials, and measures to minimize economic and health consequences to the oral health system.

\section{Microbiological aspects}

This new health problem emerged from a public market in which animals are kept and traded alive in Wuham - China. It became the focus of global attention after the spread of an unknown cause epidemic pneumonia. At first, these cases of pneumonia were monitored and tested in the laboratory for coronavirus and possible influenza infections. On January 7, 2020, Chinese authorities announced that a new type of Coronavirus was isolated: the new Coronavirus, $\mathrm{nCoV}^{14}$

This new viral agent, which until that moment has not been identified in humans before, was called SARS-CoV-2 and is able to cause respiratory infectious disease that is called COVID-19. Previous occurrence of coronavirus such as the Severe Acute Respiratory Syndrome (SARS) (SARS-CoV) and Middle East Respiratory Syndrome (MERS) (MERS-CoV) left 774 and 850 dead, respectively, reflecting the severity of the threat and the urgency to control this new outbreak as soon as possible. ${ }^{15}$

The genomic sequence of the new viral Coronavirus was immediately defined by public health support and online community resources "virological.org" on January $10^{\text {th }}$ (Wuhan-Hu-1, GenBank accession number MN908947) ${ }^{16}$ followed by four other deposited genomes on January $12^{\text {th }}$ in the database of viral genomic sequences maintained by the Global Initiative on Sharing All Influenza Data (GISAID) ${ }^{17}$ The clinical signs and symptoms in the beginning suggested the presence of a virus closely related to SARS outbreak in 2002/2003. This species also comprised a large number of viruses detected in rhinolophid bats in Asia and Europe. ${ }^{17}$ After sequencing, the SARS-CoV-2 genome was found to be $96.2 \%$ identical to the Bat RaTG13 coV, while sharing $79.5 \%$ identity with the SARS-CoV. In this way, the similarity between the genomes of the viruses shows that the bat is the natural host of the virus and SARSCoV-2 may have been transmitted to humans, in an unknown way, through intermediate hosts. Several studies suggest that the bat is the potential reservoir of SARS-CoV-2. However, there is evidence that the origin of SARS-CoV-2 was the seafood market in Wuhan, China. ${ }^{18}$ Coronaviruses $(\mathrm{CoV}) \alpha-$ and $\beta-\mathrm{CoV}$ are capable of infecting mammals, while $\gamma$ - and $\delta-\mathrm{CoV}$ tend to infect birds. Although the six CoVs identified as human-susceptible viruses, presented low pathogenicity, causing mild respiratory symptoms similar to a common cold; SARS-CoV and MERS-CoV may lead to severe and potentially fatal respiratory tract infections. ${ }^{18,19}$ 
Viruses are complex pathogens with a high capacity to infect multiple host species, causing a variety of diseases with numerous symptoms. CoVs are pleomorphic RNA-viruses (subgenus sarbecovirus, subfamily Orthocoronavirinae) characterized by high speed of gene recombination due to constant errors in their RNA polymerase-dependent replication process (RdRP). ${ }^{18,20}$ The main steps involved in the replication cycle of SARS-CoV-2 are: recognition and binding to the host cell via membrane fusion or endocytosis mechanism. After the invasion, the viral genome is released; then occurs translation of the viral polymerase protein; RNA replication; subgenomic transcription; translation of viral structural proteins; viral structural proteins combination with the nucleocapsid; formation of mature virions and finally the release of mature virions by exocytosis. At the end of the cycle, newly mature virions are released and may infect new targets and the cycle repeats itself continuously. ${ }^{15}$ During their replication cycle, two-thirds of the viral RNA encode 16 non-structural proteins (NSPs). The other one-third of the virus genome encodes four essential structural proteins, including: spike glycoprotein (S), small envelope protein (E), matrix protein (M) and nucleocapsid protein $(\mathrm{N})$, and also other accessory proteins. ${ }^{18,21}$

Host factors can also influence susceptibility to infection and disease progression. Research shows that SARS-CoV-2 use angiotensin-converting enzyme 2 (ACE2). The S-glycoprotein located on the surface of the coronavirus can bind to the ACE2 receptor on the surface of human cells. After binding to the host cell membrane, the RNA of the viral genome is released into the cytoplasm and translates two polyproteins, ppla and pplab that encode non-structural proteins and form the replication and transcription complex (RTC) and the replication cycle continues as stated above ${ }^{18}$. Host antiviral defense plays an important role in the course of SARS-CoV-2 infection. As the first line of defense against viruses, type I interferon (IFN) plays a critical role in initiating host antiviral responses. Following virus infection, the host innate immune system is activated by the recognition of viral-specific components such as ssRNA, dsRNA or glycoproteins. ${ }^{22}$ The Toll-like and RIG-I-like receptors are the most common host pattern recognition receptors (PRRs) that respond to RNA viruses. ${ }^{23}$ The domains then initiate an antiviral signaling cascade by leading the phosphorylation and activation of IRF3 and NF-kB, leading to the production of type I IFN. IFN- $\beta$ secretion induces IFN-stimulated genes, which will induce the expression of host antiviral effector factors. ${ }^{24}$

Viruses have developed the capacity to escape host immune detection and to suppress the host IFN system. ${ }^{25}$ Viruses encode viral proteins that interfere with PRRs signaling pathways to increase an early benefit against host defense. For example, the SARS-CoV N proteins inhibit RIG-I ubiquitination and thus suppress the release of type I IFN,${ }^{26}$ SARS-CoV M proteins prevents the TRAF3/ TBK1 complex formation and inhibits TBK1/IKKEdependent activation of IRF3/IRF7 transcription factors. ${ }^{27}$ Lastly, the repressive modifications that are induced by the nonstructural SARS-CoV nsp1 protein blocks host mRNA translation ${ }^{28}$ and mediates host mRNA degradation. ${ }^{29}$

Human-to-human transmission of SARS-CoV-2 occurs primarily between family members, including relatives and friends who have more intimate contact with infected or asymptomatic patients or carriers. As an emerging acute respiratory infectious disease, COVID-19 spreads mainly through the respiratory tract pathways through droplets, respiratory secretions and direct contact even at a low infectious dose. Likewise, the presence of SARS-CoV-2 in swabs from fecal and blood samples has been identified, indicating the possibility of multiple routes of infection..$^{18}$

Based on the current epidemiological investigation, the incubation period is from 1 to 14 days, mainly from 3 to 7 days, being contagious in its latency period. It is highly transmissible in humans, especially in the elderly and people with underlying diseases. Patients with COVID-19 have symptoms such as fever, malaise and cough. Most adults or children infected with SARS-CoV-2 have mild flu-like symptoms. However, a few patients also progress to a critical condition and rapidly develop acute respiratory distress syndrome, respiratory failure, multiple organ failure and even die. ${ }^{18,30}$ There are still many gaps in knowledge about the epidemiology and clinical overview of COVID-19, including the exact incubation period, the possibility 
of transmission from asymptomatic carriers and the rate of transmissibility. However, human-human transmission has been rapidly proven and remains responsible for the continued spread of the disease.

Reliable laboratory diagnosis is among the priorities to facilitate public health interventions. In acute respiratory infections, RT-PCR is routinely used to detect viruses caused by respiratory secretions. During international health emergencies, the viability of real-time detection of the virus by real-time RT-PCR has been demonstrated through coordination between public laboratories and universities. ${ }^{17}$

\section{SARS-CoV-2 Drug Therapy}

Drugs tested effective for SARS-CoV and/or MERS have been included in the WHO mega clinical trial SOLIDARITY. ${ }^{31}$ For its study, WHO chose a nucleotide analogue Remdesivir; the malaria medication chloroquine (and its analog hydroxychloroquine); a combination of the anti-HIV drugs lopinavir and ritonavir; and that combination plus interferon-b.

Remdesivir is an antiviral prodrug of remdesivirtriphosphate with in vitro activity against coronaviruses. ${ }^{32,33}$ Remdesivir-TP acts as an inhibitor of RNA-dependent RNA polymerases and competes with adenosine-TP for incorporation into emerging viral RNA chains. ${ }^{34}$ Hydroxyhloroquine and chloroquine have in vitro activity against SARS-CoV-2 ${ }^{32,35-37}$ and the mechanism of action includes inhibition of viral enzymes (RNA polymerase), viral protein glycosylation, virus assembly, new virus particle transport, and virus release. Other mechanisms may also involve ACE2 receptor inhibition, decrease acidity in endosomes, and immunomodulation of cytokine release. ${ }^{5,32,36}$

The third arm of SOLIDARITY combines two HIV protease inhibitor drugs, lopinavir-ritonavir. The combination shown in vitro and in vivo potential activity for SARS-CoV and MERS-CoV ${ }^{38,39}$ and the mechanism of action involves the inhibition of $\mathrm{M}^{\text {pro, }}$, an essential enzyme for coronavirus replication ${ }^{40}$. Recent report published in The New England Journal of Medicine ${ }^{41}$ was not encouraging and the combination of lopinavir-ritonavir did not differ significantly from "standard care" group.
The fourth arm of SOLIDARITY combines lopinavir-ritonavir with interferon-b. The activation of innate antiviral response by interferon should have beneficial effects at least in the initial stage of infection. However, cautions should still be observed and the possibility that interferon might exacerbate inflammation during the late phase of SARS-CoV-2 infection cannot be excluded. ${ }^{42}$

Lastly, clinical trials are being conducted to evaluate the use of SARS-CoV-2 convalescent plasma from persons who have recovered from COVID-19 that potentially contain antibodies to treat patients with life-threatening viral infections. ${ }^{43}$ A group led by Lei $\mathrm{Liu}^{44}$ gave convalescent plasma (total dose: $400 \mathrm{~mL}$ with a SARS-CoV-2-specific antibody-IgG titer greater than 1:1,000) to five critically ill patients and the symptoms diminished in all of them within ten days. Even though these cases reported by Shen et al ${ }^{44}$ are compelling, this investigation has some limitations. The intervention was not evaluated in a randomized clinical trial, and the outcomes in the treatment group were not compared with outcomes in a control group - patients who did not receive the intervention. Moreover, patients received numerous other therapies (antiviral and steroids), and the convalescent plasma was administered up to 21 days, and it is not clear whether this timing is optimal or if earlier administration potentially have been associated with different outcomes. Despite these limitations, the study does provide important evidence to support the possibility of evaluating this therapy in more rigorous studies.

\section{Dental practice in the Covid-19 scenario}

\section{Risk scenario}

Dentists are among the professionals with the greatest exposure to COVID-19. The oral cavity and the work environment represent a high potential source for transmissibility and susceptibility to this and other etiological agents. ${ }^{7,45,46}$ The context of undocumented infections is significant, which facilitates the rapid spread of SARS-CoV-2. A substantial number of individuals do not show any signs and symptoms or have mild symptoms. These individuals serve 
as the primary source for the majority of reported cases and, therefore, for health teams that can become multipliers. ${ }^{47,48}$

The rapid identification of COVID-19 cases is crucial for the containment of the pandemic. However, it is still challenging due to the lack of pathognomonic symptoms, coupled with the limited capacity to perform specialized polymerase chain reaction (PCR) tests ${ }^{49}$ - which also have limitations. The need to develop fast accurate molecular diagnostics is mandatory to identify a large number of infected patients and asymptomatic carriers, in order to prevent the transmission of the virus and ensure proper conduct. ${ }^{50,51}$ Rapid tests can facilitate elective care in the future since the risk of contamination by SARS-CoV-2 would be ruled out. However, the dentist can never neglect the existence of other diseases transmitted by saliva and aerosol, such as hepatitis B, measles and tuberculosis. ${ }^{52,53,54}$

Dentists should receive and make great efforts regarding preventive care and testing, as they can seriously affect the flattening of the epidemic curve, avoiding the collapse of the health system. Several modeling studies and scenario comparisons - both related to the current pandemic situation and those already experienced especially in China and Italy - have shown that combined interventions must be implemented, both for the population and for health professionals. General measures for all health professionals including dentists comprise daily monitoring of the temperature and testing the health care provider team; use of N95 masks; distance from the workplace (when possible) with the implementation of network communication technologies with patients; social distance; mobility restriction measures; avoid crowd places; diagnostic tests and isolation of infected individuals as well as their families. ${ }^{5-60}$ Especially for dentists it is necessary to follow guidance protocols and new tools/technologies for dental practice aimed at safeguarding oral health professionals, as well as the population under their care. ${ }^{59,61}$

\section{Dental treatment during the Covid-19 Pandemic}

Due to the nature of the dental treatment, several procedures, as the use of high-speed handpiece or ultrasonic scalers generates aerosol (very small particles or droplets) that can be inhaled, absorbed by the skin or set in nearby surfaces. ${ }^{62}$ According to the last Scientific Brief published by the World Health Organization, ${ }^{63}$ the transmission of the SARS-CoV-2 can occur by respiratory droplets from direct contact with an infected person (distance less than $1 \mathrm{~m}$ ), indirect contact with contaminated surfaces or objects and by aerosol produced during procedures performed on infected patients. Based on that, dental and health organizations have issued recommendations to postpone all elective dental treatments and non-essential procedures and limit services only to urgent and emergency visits. ${ }^{10,11,12}$ Dental health care personnel (DHCP) should be aware of the mechanisms of transmission, the expanded infection control procedures, be able to identify patients with signs / symptoms of COVID-19 and have a clear understanding of what characterizes a dental emergency, urgent dental care and nonemergency dental treatment.

During the COVID-19 pandemic, DCHP should use telecommunication or teledentistry prior the dental treatment to evaluate the needs of the patient and to minimize the risk of infection, asking if patient has fever, cough or shortness of breath (ADA) ${ }^{64}$ and have traveled national or internationally (CDC). ${ }^{65,66}$ When possible, dentist should offer advice, prescribe medication for analgesia and/or antimicrobial (when appropriate) and postpone the visit of the patient to the office, but keep direct contact with the patient by phone or text message. ${ }^{67}$ If patient presents a dental emergency (potentially life threatening), as an uncontrolled bleeding, or an urgent dental need that requires relieve of severe pain and/or risk of infection, ${ }^{68}$ and present sign/symptom of respiratory infection, this patient should not be seen in a dental office and should be referred for an emergency care facility where Transmission-Based Precautions (N95 masks, Airborne Infection Isolation Room for example) are available (ADA). ${ }^{64}$

In the United Kingdom, the National Health Service (NHS) is working with dental practices and community dental services to establish Local Dental Urgent Care System in every region. These dental offices will accommodate visits of all types of 
patients, including those with suspected or confirmed COVID-19, patients that are shielded, vulnerable or patients without any of those specific conditions. In those places dental public health practitioners will be available and will have access to the FFP3 respirator to perform the treatment. ${ }^{67}$

In most countries, cases of dental emergency or urgent dental care on patients without any signs and symptoms of COVID-19 can be treated at the dental office. However, since there is a large number of asymptomatic cases of Covid-19, ${ }_{r}^{47}$ the dentist should take extra precautions when seeing the patient and not assume he/she is COVID-19 free. Besides the asymptomatic patients, dental practitioners should be aware that children represent a significant transmission risk to the virus since they present milder symptoms than adults. ${ }^{69}$ It is important to maintain patient isolation (have only one patient in the waiting room), adhere to the infection control protocol: standard procedure of putting on and removing all Personal Protective Equipment (PPE), including gown, goggles, N95 mask with face full shield and gloves. ${ }^{64}$ Before every treatment, patient should use a mouth rinse with $1 \%$ or $1.5 \%$ hydrogen peroxide or $0.2 \%$ povidone ${ }^{9,64}$ and should wear goggles and bib during the whole procedure. To minimize the aerosol production, dentists should use hand instrumentation, high-volume saliva ejector and dental dam during the treatment and refrain to use 3-in-1 syringe. ${ }^{61}$

Intraoral radiographs should be avoided since it can induce coughing; the office space should be limited to the patient and to the operator and dental assistant. After the treatment, the DCHP should wear appropriate PPE to proceed with the cleaning and disinfection of the room and equipment using the recommended disinfecting products. ${ }^{64}$ Besides, dentists should reconsider the use of sedation (inhalation and pharmacological) to manage severe anxiety or phobia in the dental settings and focus on non-pharmacological techniques to minimize the potential risk of needing life support measures that involve the manipulation of airways and aerosolization (inhalation sedation). ${ }^{8}$

In a specific situation where the patient has an unavoidable emergency and no signs and symptoms of COVID-19 and the dentist does not have a N95 mask or higher level, he/she must wear surgical mask in a single use, goggles and face shield to treat a patient, but be aware that the risk of contamination will be moderate. ${ }^{64}$ There is a limitation in following this procedure since there is current community spread of COVID-19 with asymptomatic cases in the population. Current research shows that the prognosis of patients with COVID-19 is worst for those older than 60 years of age or presenting underlying diseases (diabetes, hypertension or cardiovascular disease, for example).$^{70}$ In this sense, members of the health team must use clinical judgment and take all precautions to prevent transmission.

In this unprecedented situation, it is advisable to look for and apply the most recent protocols and guidance from your local dental organizations in your country that are based in the current literature and be aware that the COVID-19 pandemic brings challenges to the dental health care providers not only on their practices but on their financial situation as well. A general flowchart (Figure) was constructed based on the ADA's Interim guidance on minimizing COVID-19 transmission risk when treating dental emergencies. ${ }^{64}$ As also stated in this ADA's document, ${ }^{64}$ Figure 1 does not constitute legal advice or legal guidance. It only helps clinicians for their own judgment about the risks of infection while working in dental offices.

\section{Perspectives}

Health professionals are facing new challenges in providing care to their patients. Remote treatment via chat, video conversation, telemedicine, teledentistry and other technologies have given rise to a new look at the professional-patient relationship, opening doors to an untapped universe, since most dentists do not use them as part of their daily work. ${ }^{71}$ It is estimated that by 2025 over $60 \%$ of the population will be using mobile internet. ${ }^{72}$ Therefore, mobile technologies, including phones, are great allies to community health even in low and middle-income population. ${ }^{73-75}$ Individuals that still do not have access to mobile services would also benefit due to diminishing waiting lines in local health assistance, at the nearest Primary Health Units. 


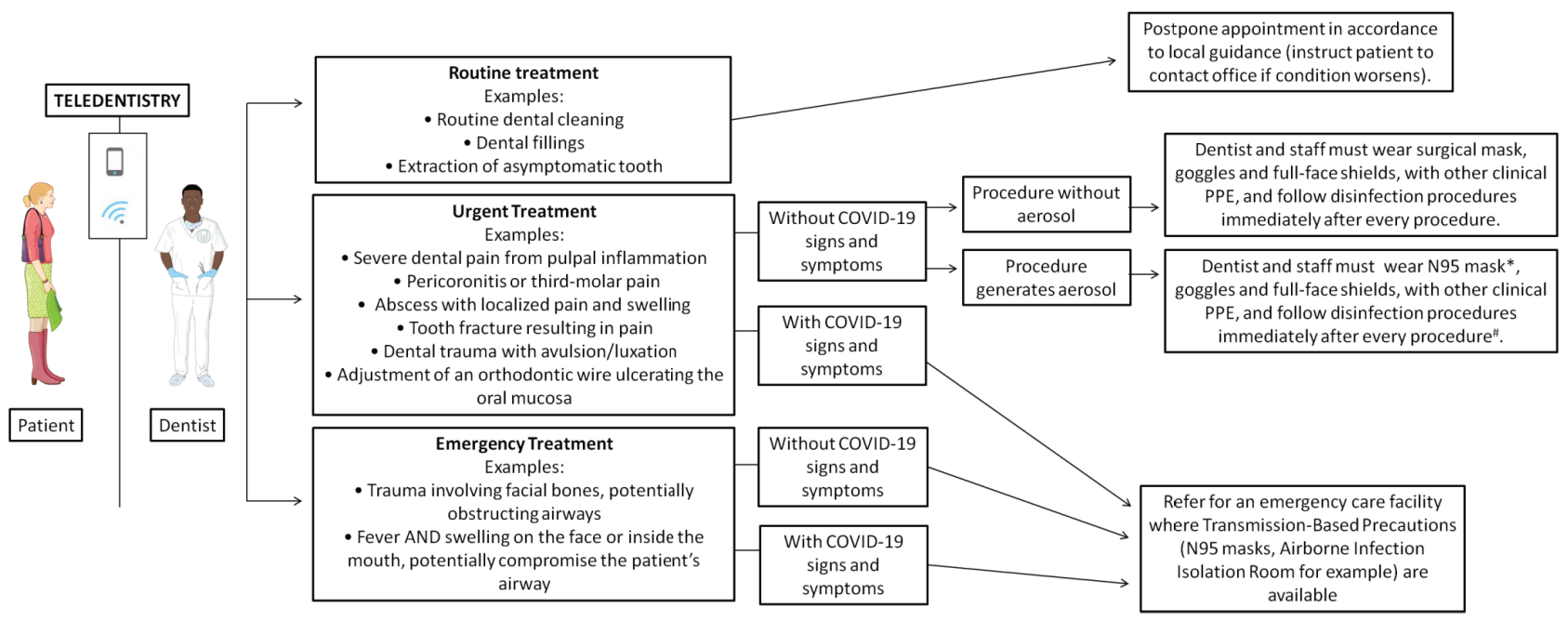

*Use of N95 mask denotes low risk of infection

\# If no N95 available, refer patient to a facility that has N95. If not feasible, use your clinical judgment and precautions of infection control. Dentist and staff must wear surgical facemasks, goggles and full-face shields, with other basic clinical PPE and follow disinfection procedures immediately after every procedure. Use of surgical facemasks denotes moderate risk of infection. DCHP should quarantine for 14 days and communicate with patients that were seen after that day. Procedures involving aerosol should be scheduled for the last appointment of the day. Dentists should avoid intra-oral radiographs, prefer hand instrumentation, and use high-volume saliva ejector and dental dam during the treatment.

This figure was constructed using free images obtained at: https://smart.servier.com/ and https://www.freepik.com/.

Figure 1. Flowchart based on the American Dental Association Interim Guidance for Management of Emergency and Urgent Dental Care on 04/01/2020 and do not constitute legal advice or legal guidance.

In private offices, the limitation on dental and medical activities to only urgent and emergency procedures presents a strong impact on the economy of these sectors. ${ }^{76}$ This economic crises have raised reflections and concerns that go beyond clinical security and social detachment and have highlighted the importance of social security and financial education. Such factors must also be taken into account by the entities that guide dental practice, in order to generate discussions to support the dentists on those occasions where they will have to keep distance from their routine clinical tasks during COVID-19.

The dental class, which comprises in its vast majority, autonomous professionals, should recover the issues of financial education, frequently so distant from the contents of the academic curriculum. There is an evident scarcity of articles related to financial education for dental offices. Emergency financial reserve, funds to deposit this reserve and long-term investments, public or private pension, should be part of the incisive recommendations to this group. Other professional classes are raising these issues concerning this urgent moment to guarantee social security for all and to go beyond the packages proposed by governments. ${ }^{77}$ Such strategies must be sustainable, long-term, with a view to protecting the self-employed and avoiding an unprecedented economic crisis.

\section{Conclusions}

This recent COVID-19 turned into a global public health outbreak. It is transmitted after contact with infected surfaces and with infected patient's fluids, including saliva and aerosol. A substantial number of individuals do not show any signs and symptoms and may disseminate the virus. These characteristics put the dental offices as main risk settings of cross infection among patients and dentists. Currently there is no effective treatment and fast diagnosis is still a challenge. All elective dental treatments and non-essential procedures should be postponed, keeping only urgent and emergency visits to the dental office. Unexpected situations like this pandemic, 
brings financial issues to the dental team; in this way, financial education become very important subject to be discussed during the professional school. The use of telecommunication (phone calls, text messages) and teledentistry are very promising tools to keep contact with the patient without put them in high risk of infection.

\section{Acknowledgments}

National Council for Scientific and Technological Development (Conselho Nacional de Desenvolvimento Científico and Tecnológico - CNPq), and the Coordination for the Improvement of Higher Education Personnel (Coordenação de Aperfeiçoamento de Nível Superior - CAPES).

\section{References}

1. Corman VM, Muth D, Niemeyer D, Drosten C. Hosts and sources of endemic human coronaviruses. Adv Virus Res. 2018;100:163-88. https://doi.org/10.1016/bs.aivir.2018.01.001

2. Marra MA., Jones SJM., Astell CR., Holt RA., Brooks-Wilson A., Butterfield YSN., et al. The genome sequence of the SARS-associated coronavirus. Science. 2003 May;300(5624):1399-404. https://doi.org/10.1126/science.1085953

3. Wolff MH, Sattar SA, Adegbunrin O, Tetro J. Environmental survival and microbicide inactivation of coronaviruses. In: Schmidt A, Wolff $\mathrm{MH}$, Weber O. Coronaviruses with special emphasis on first insights concerning SARS. Base: Birkhäuser; 2005. p. $201-12$.

4. Abbag HF, El-Mekki AA, Al Bshabshe AA, Mahfouz AA, Al-Dosry AA, Mirdad RT, et al. Knowledge and attitude towards the Middle East respiratory syndrome coronavirus among healthcare personnel in the southern region of Saudi Arabia. J Infect Public Health. 2018 Sep - Oct;11(5):720-2. https://doi.org/10.1016/i.jiph.2018.02.001

5. Cortegiani A, Ingoglia G, Ippolito M, Giarratano A, Einav S. A systematic review on the efficacy and safety of chloroquine for the treatment of COVID-19. J Crit Care. 2020 Mar; pii::S0883-9441(20)30390-7. https://doi.org/10.1016/i.jcrc.2020.03.005

6. Doremalen N, Bushmaker T, Morris DH, Holbrook MG, Gamble A, Williamson BN, et al. Aerosol and surface stability of SARS-CoV-2 as compared with SARS-CoV-1. N Engl J Med. 2020 Mar;NEJMc2004973. https://doi.org/10.1056/NEJMc2004973

7. Sabino-Silva R, Jardim AC, Siqueira WL. Coronavirus COVID-19 impacts to dentistry and potential salivary diagnosis. Clin Oral Investig. 2020 Apr;24(4):1619-21. https://doi.org/10.1007/s00784-020-03248-x

8. Souza RC, Costa PS, Costa LR. Dental sedation precautions and recommendations during the COVID-19 pandemic. Braz J Dent. 2020 Apr;77(0):1-3. https://doi.org/10.18363/RBO.V77.2020.E1788

9. Peng X, Xu X, Li Y, Cheng L, Zhou X, Ren B. Transmission routes of 2019-nCoV and controls in dental practice. Int J Oral Sci. 2020 Mar;12(1):9. https://doi.org/10.1038/s41368-020-0075-9

10. Ministério da Saúde (BR). Secretaria de Atenção Primária à Saúde (SAPS). . Atendimento odontológico no SUS. Brasília, DF; 2020. [cited 2020 Mar 31]. Available from: http://www.crosp.org.br/uploads/arquivo/ab69d79b87d04780af08a70d8cee9d70.pdf

11. Centers of Disease Control and Prevention - CDC. Recommendation: postpone non-urgent dental procedures, surgeries, and visits. centers of disease control and prevention. 2020 [cited 2020 Mar 31]. Available from: https://www.cdc.gov/oralhealth/infectioncontrol/ statement-COVID.html

12. American Dental Association - ADA. ADA recommending dentists postpone elective procedures. American Dental Assocaition. 2020 [cited 2020 Mar 31]. Available from: https://www.ada.org/en/publications/ada-news/2020-archive/march/ada-recommending-dentistspostpone-elective-procedures

13. Meng L, Hua F, Bian Z. Coronavirus disease 2019 (COVID-19): emerging and future challenges for dental and oral medicine. J Dent Res. 2020 Mar:22034520914246. https://doi.org/10.1177/0022034520914246

14. Sahin A, Erdogan A, Mutlu Agaoglu P, Dineri Y, Cakirci A, Senel M, et al. 2019 Novel Coronavirus (COVID-19) outbreak: a review of the current literature. Eurasian J Med Investig. 2020;4(1):1-7. https://doi.org/10.14744/ejmo.2020.12220

15. Iqbal HM, Romero-Castillo KD, Bilal M, Parra-Saldivar R. The emergence of novel-coronavirus and its replication cycle: an overview. J Pure Appl Microbiol. 2020;14(March):6146.

16. Wu F, Zhao S, Yu B, Chen YM, Wang W, Song ZG, et al. A new coronavirus associated with human respiratory disease in China. Nature. 2020 Mar;579(7798):265-9. https://doi.org/10.1038/s41586-020-2008-3

17. Corman VM, Landt O, Kaiser M, Molenkamp R, Meijer A, Chu DK, et al. Detection of 2019 novel coronavirus (2019-nCoV) by real-time RT-PCR. Euro Surveill. 2020 Jan;25(3). https://doi.org/10.2807/1560-7917.ES.2020.25.3.2000045

18. Chen Y, Liu Q, Guo D. Emerging coronaviruses: genome structure, replication, and pathogenesis. J Med Virol. 2020 Apr;92(4):418-23. https://doi.org/10.1002/jmv.25681 
19. Cui J, Li F, Shi ZL. Origin and evolution of pathogenic coronaviruses. Nat Rev Microbiol. 2019 Mar;17(3):181-92. https://doi.org/10.1038/s41579-018-0118-9

20. Su S, Wong G, Shi W, Liu J, Lai AC, Zhou J, et al. Epidemiology, genetic recombination, and pathogenesis of coronaviruses. Trends Microbiol. 2016 Jun;24(6):490-502. https://doi.org/10.1016/i.tim.2016.03.003

21. Hussain S, Pan J, Chen Y, Yang Y, Xu J, Peng Y, et al. Identification of novel subgenomic RNAs and noncanonical transcription initiation signals of severe acute respiratory syndrome coronavirus. J Virol. 2005 May;79(9):5288-95. https://doi.org/10.1128/JVI.79.9.5288-5295.2005

22. Kato H, Takeuchi O, Sato S, Yoneyama M, Yamamoto M, Matsui K, et al. Differential roles of MDA5 and RIG-I helicases in the recognition of RNA viruses. Nature. 2006 May;441(7089):101-5. https://doi.org/10.1038/nature04734

23. Chan YK, Gack MU. Viral evasion of intracellular DNA and RNA sensing. Nat Rev Microbiol. 2016 Jun;14(6):360-73. https://doi.org/10.1038/nrmicro.2016.45

24. Schneider WM, Chevillotte MD, Rice CM. Interferon-stimulated genes: a complex web of host defenses. Annu Rev Immunol. 2014;32(1):513-45. https://doi.org/10.1146/annurev-immunol-032713-120231

25. Kindler E, Thiel V, Weber F. Interaction of SARS and MERS Coronaviruses with the Antiviral Interferon Response. Adv Virus Res. 2016;96:219-43. https://doi.org/10.1016/bs.aivir.2016.08.006

26. Hu Y, Li W, Gao T, Cui Y, Jin Y, Li P, et al. The severe acute respiratory syndrome coronavirus nucleocapsid inhibits type i interferon production by interfering with TRIM25-Mediated RIG-I Ubiquitination. J Virol. 2017 Mar;91(8):e02143-16. https://doi.org/10.1128/JVI.02143-16

27. Siu KL, Kok KH, Ng MH, Poon VK, Yuen KY, Zheng BJ, et al. Severe acute respiratory syndrome coronavirus M protein inhibits type I interferon production by impeding the formation of TRAF3.TANK.TBK1/IKKepsilon complex. J Biol Chem. 2009 Jun;284(24):16202-9. https://doi.org/10.1074/ibc.M109.008227

28. Tanaka T, Kamitani W, DeDiego ML, Enjuanes L, Matsuura Y. Severe acute respiratory syndrome coronavirus nspl facilitates efficient propagation in cells through a specific translational shutoff of host mRNA. J Virol. 2012 Oct;86(20):11128-37. https://doi.org/10.1128/JVI.01700-12

29. Huang C, Lokugamage KG, Rozovics JM, Narayanan K, Semler BL, Makino S. SARS coronavirus nspl protein induces templatedependent endonucleolytic cleavage of mRNAs: viral mRNAs are resistant to nspl-induced RNA cleavage. PLoS Pathog. 2011 Dec;7(12):e1002433. https://doi.org/10.1371/journal.ppat.1002433

30. Sun J, He WT, Wang L, Lai A, Ji X, Zhai X, et al. COVID-19: Epidemiology, Evolution, and Cross-Disciplinary Perspectives. Trends Mol Med. 2020 Mar 21.https://doi.org/10.1016/j.molmed.2020.02.008

31. World Health Organization - WHO. "Solidarity" clinical trial for COVID-19 treatments. 2020 [cited 2020 Apr 10]. Available from: https://www.who.int/emergencies/diseases/novel-coronavirus-2019/global-research-on-novel-coronavirus-2019-ncov/solidarity-clinicaltrial-for-covid-19-treatments

32. Wang M, Cao R, Zhang L, Yang $X$, Liu J, Xu M, et al. Remdesivir and chloroquine effectively inhibit the recently emerged novel coronavirus (2019-nCoV) in vitro. Cell Res. 2020 Mar;30(3):269-71. https://doi.org/10.1038/s41422-020-0282-0

33. Agostini ML, Andres EL, Sims AC, Graham RL, Sheahan TP, Lu X, et al. Coronavirus susceptibility to the antiviral remdesivir (GS-5734) is mediated by the viral polymerase and the proofreading exoribonuclease. MBio. 2018 Mar;9(2):e00221-18. https://doi.org/10.1128/mBio.00221-18

34. Brown AJ, Won JJ, Graham RL, Dinnon KH 3rd, Sims AC, Feng JY, et al. Broad spectrum antiviral remdesivir inhibits human endemic and zoonotic deltacoronaviruses with a highly divergent RNA dependent RNA polymerase. Antiviral Res. 2019 Sep;169:104541. https://doi.org/10.1016/j.antiviral.2019.104541

35. Gao J, Tian Z, Yang X. Breakthrough: chloroquine phosphate has shown apparent efficacy in treatment of COVID-19 associated pneumonia in clinical studies. Biosci Trends. 2020 Mar;14(1):72-3. https://doi.org/10.5582/bst.2020.01047

36. Yao X, Ye F, Zhang M, Cui C, Huang B, Niu P, et al. In Vitro antiviral activity and projection of optimized dosing design of Hydroxychloroquine for the treatment of severe acute respiratory syndrome Coronavirus 2 (SARS-CoV-2). Clin Infect Dis. 2020 Mar:ciaa237. https://doi.org/10.1093/cid/ciaa237

37. Colson P, Rolain JM, Lagier JC, Brouqui P, Raoult D. Chloroquine and hydroxychloroquine as available weapons to fight COVID-19. Int J Antimicrob Agents. 2020 Mar;105932:105932. https://doi.org/10.1016/i.ijantimicag.2020.105932

38. Chen F, Chan KH, Jiang Y, Kao RY, Lu HT, Fan KW, et al. In vitro susceptibility of 10 clinical isolates of SARS coronavirus to selected antiviral compounds. J Clin Virol. 2004 Sep;31(1):69-75. https://doi.org/10.1016/i.jcv.2004.03.003

39. Yao TT, Qian JD, Zhu WY, Wang Y, Wang GQ. A systematic review of lopinavir therapy for SARS coronavirus and MERS coronavirus: a possible reference for coronavirus disease-19 treatment option. J Med Virol. 2020 Feb:jmv.25729. https://doi.org/10.1002/jmv.25729

40. Liu X, Wang XJ. Potential inhibitors against 2019-nCoV coronavirus M protease from clinically approved medicines. J Genet Genomics. 2020 Feb;47(2):119-21. https://doi.org/10.1016/i.jgg.2020.02.001 
41. Cao B, Wang Y, Wen D, Liu W, Wang J, Fan G, et al. A trial of lopinavir-ritonavir in adults hospitalized with Severe Covid-19. N Engl J Med. 2020 Mar:NEJMoa2001282. https://doi.org/10.1056/NEJMoa2001282

42. Kupferschmidt K., Cohen J. Race to find COVID-19 treatments accelerates. Science. 2020 Mar;367(6485):1412-3. https://doi.org/10.1126/science.367.6485.1412

43. FDA. Recommendations for investigational COVID-19 Convalescent Plasma. 2020 [cited 2020 Apr 6]. Available from: https://www. fda.gov/vaccines-blood-biologics/investigational-new-drug-ind-or-device-exemption-ide-process-cber/investigational-covid-19convalescent-plasma-emergency-inds

44. Shen C, Wang Z, Zhao F, Yang Y, Li J, Yuan J, et al. Treatment of 5 critically ill patients with COVID-19 with convalescent plasma. JAMA. 2020 Mar. https://doi.org/10.1001/jama.2020.4783

45. Harrel SK, Molinari J. Aerosols and splatter in dentistry: a brief review of the literature and infection control implications. J Am Dent Assoc. 2004 Apr;135(4):429-37. https://doi.org/10.14219/jada.archive.2004.0207

46. Xu H, Zhong L, Deng J, Peng J, Dan H, Zeng X, et al. High expression of ACE2 receptor of 2019-nCoV on the epithelial cells of oral mucosa. Int J Oral Sci. 2020 Feb;12(1):8. https://doi.org/10.1038/s41368-020-0074-x

47. Li R, Pei S, Chen B, Song Y, Zhang T, Yang W, et al. Substantial undocumented infection facilitates the rapid dissemination of novel coronavirus (SARS-CoV2). Science. 2020 Mar;eabb3221. https://doi.org/10.1126/science.abb3221

48. Wang D, Hu B, Hu C, Zhu F, Liu X, Zhang J, et al. Clinical Characteristics of 138 Hospitalized Patients With 2019 Novel CoronavirusInfected Pneumonia in Wuhan, China. JAMA. 2020 Feb;323(11):1061. https://doi.org/10.1001/jama.2020.1585

49. Sun Y, Koh V, Marimuthu K, Ng OT, Young B, Vasoo S, et al. Epidemiological and clinical predictors of COVID-19. Clin Infect Dis. 2020 Mar:ciaa322. https://doi.org/10.1093/cid/ciaa322

50. Lee Y, Kang BH, Kang M, Chung DR, Yi GS, Lee LP, et al. Nanoplasmonic on-chip PCR for rapid precision molecular diagnostics. ACS Appl Mater Interfaces. 2020 Mar;12(11):12533-40. https://doi.org/10.1021/acsami.9b23591

51. Li Z, Yi Y, Luo X, Xiong N, Liu Y, Li S, et al. Development and clinical application of a rapid IgM-lgG combined antibody test for SARSCoV-2 infection diagnosis. J Med Virol. 2020 Feb:jmv.25727. https://doi.org/10.1002/jmv.25727

52. Centers of Disease Control and Prevention - CDC. How TB Spreads. 2020 [Cited 2020 Apr 6]. Available from: https://www.cdc.gov/tb/topic/basics/howtbspreads.htm.evention.

53. Centers of Disease Control and Prevention - CDC. Transmission of measles. 2020 [cited 2020 Apr 6]. Available from: https://www.cdc.gov/measles/transmission.html

54. Centers of Disease Control and Prevention - CDC. Hepatitis B questions and answers for health professionals. 2020 [cited 2020 Apr 6]. Available from: https://www.cdc.gov/hepatitis/hbv/hbvfaq.htm\#treatmenthttps://www.cdc.gov/measles/transmission.html

55. Lau H, Khosrawipour V, Kocbach P, Mikolajczyk A, Schubert J, Bania J, et al. The positive impact of lockdown in Wuhan on containing the COVID-19 outbreak in China. J Travel Med. 2020 Mar:taaa037. https://doi.org/10.1093/jtm/taaa037

56. Ma QX, Shan H, Zhang HL, Li GM, Yang RM, Chen JM. Potential utilities of mask-wearing and instant hand hygiene for fighting SARS-CoV-2. J Med Virol. 2020 Mar: https://doi.org/10.1002/jmv.25805

57. Pan X, Ojcius DM, Gao T, Li Z, Pan C, Pan C. Lessons learned from the 2019-nCoV epidemic on prevention of future infectious diseases. Microbes Infect. 2020 Mar;22(2):86-91. https://doi.org/10.1016/j.micinf.2020.02.004

58. Kraemer MUG, Yang C-H, Gutierrez B, Wu C-H, Klein B, Pigott DM, et al. The effect of human mobility and control measures on the COVID-19 epidemic in China. Science. 2020;4218(March):eabb4218. https://doi.org/10.1126/science.abb4218

59. Tan CC. SARS in Singapore: key lessons from an epidemic. Ann Acad Med Singapore. 2006 May;35(5):345-9.

60. Koo JR, Cook AR, Park M, Sun Y, Sun H, Lim JT, et al. Articles Interventions to mitigate early spread of SARS-CoV-2 in Singapore: a modelling study. Lancet Infect Dis. 2020;3099(20):1-11. https://doi.org/10.1016/S1473-3099(20)30162-6

61. Kharma MY, Alalwani MS, Amer MF, Tarakii B, Aws G. Assessment of the awareness level of dental students toward Middle East Respiratory Syndrome-coronavirus. J Int Soc Prev Community Dent. 2015 May-Jun;5(3):163-9. https://doi.org/10.4103/2231-0762.159951

62. Centers of Disease Control and Prevention-CDC. Aerosols | NIOSH | CDC. 2020 [cited 2020 Apr 6]. Available from: https://www.cdc.gov/niosh/topics/aerosols/

63. World Health Organization - WHO. Modes of transmission of virus causing COVID-19: implications for IPC precaution recommendations. 2020 [cited 2020 Apr 6]. Available from: https://www.who.int/news-room/commentaries/detail/modes-oftransmission-of-virus-causing-covid-19-implications-for-ipc-precaution-recommendations

64. American Dentistry Association - ADA. ADA interim guidance for minimizing risk of COVID-19 transmission. 2020 [cited 2020 Apr 1]. Available from: https://www.ada.org/ /media/CPS/Files/COVID/ADA_COVID_Int_Guidance_Treat_Pts.pdf

65. Centers of Disease Control and Prevention - CDC. Coronavirus and travel in the United States. 2020 [cited 2020 Apr 6]. Available from: https://www.cdc.gov/coronavirus/2019-ncov/travelers/travel-in-the-us.html

66. Centers of Disease Control and Prevention - CDC. Travelers returning from international travel. 2020 [cited 2020 Apr 6]. Available from: https://www.cdc.gov/coronavirus/2019-ncov/travelers/after-travel-precautions.html 
67. NHS. NHS England and NHS Improvement. Issue 3, Preparedness letter for primary dental care. 2020 Mar 25 [cited 2020 Apr 2]. Available from: https://www.england.nhs.uk/coronavirus/wp-content/uploads/sites/52/2020/03/issue-3-preparedness-letter-forprimary-dental-care-25-march-2020.pdf

68. American Dentistry Association - ADA. What constitutes a dental emergency? 2020 [cited 2020 Apr 6]. Available from: https://success. ada.org/ /media/CPS/Files/OpenFiles/ADA_COVID19_Dental_Emergency_DDS.pdf?utm_source=adaorg\&utm_medium=covidresources-lp\&utm_content=cv-pm-emerg-def\&utm_campaign=covid-19\&_ga=2.171390569.899008890.15861260661720481024.1573059269

69. Mallineni SK, Innes NP, Raggio DP, Araujo MP, Robertson MD, Jayaraman J. Coronavirus disease (COVID-19): characteristics in children and considerations for Dentists providing their care. Int J Paediatr Dent. 2020 Apr. https://doi.org/10.1111/ipd.12653

70. Cheng H, Wang Y, Wang GQ. Organ-protective effect of angiotensin-converting enzyme 2 and its effect on the prognosis of COVID-19. J Med Virol. 2020 Mar. https://doi.org/10.1002/jmv.25785

71. Wright JH, Caudill R. Remote treatment delivery in response to the COVID-19 Pandemic. Psychother Psychosom. 2020 Mar;1-3:1-3. https://doi.org/10.1159/000507376

72. GSMA. The mobile economy 2020. London: GSMA, 2020 [cited 2020 Apr 10]. Available from: https://www.gsma.com/mobileeconomy/ wp-content/uploads/2020/03/GSMA_MobileEconomy2020_Global.pdf

73. Ryan-Pettes SR, Lange LL, Magnuson KI. Mobile phone access and preference for technology-assisted aftercare among low-income caregivers of teens enrolled in outpatient substance use treatment: questionnaire study. JMIR Mhealth Uhealth. 2019 Sep;7(9):e12407. https://doi.org/10.2196/12407

74. Willcox M, Moorthy A, Mohan D, Romano K, Hutchful D, Mehl G, et al. Mobile technology for community health in Ghana: is maternal messaging and provider use of technology cost-effective in improving maternal and child health outcomes at scale? J Med Internet Res. 2019 Feb;21(2):e11268. https://doi.org/10.2196/11268

75. Pattnaik A, Mohan D, Chipokosa S, Wachepa S, Katengeza H, Misomali A, et al. Testing the validity and feasibility of using a mobile phone-based method to assess the strength of implementation of family planning programs in Malawi. BMC Health Serv Res. 2020 Mar;20(1):221. https://doi.org/10.1186/s12913-020-5066-1

76. Spagnuolo G, De Vito D, Rengo S, Tatullo M. COVID-19 outbreak: an overview on dentistry. Int J Environ Res Public Health. 2020 Mar;17(6):E2094. https://doi.org/10.3390/ijerph17062094

77. European Federation of Journalists - EFJ. COVID-19: It is time to guarantee social security for all. 2020 [cited 2020 Apr 6]. Available from: https://europeanjournalists.org/blog/2020/03/23/covid-19-it-is-time-to-guarantee-social-security-for-all/ 